DEPÓSITO LEGAL ZU2020000153

Esta publicación científica en formato digital

es continuidad de la revista impresa

ISSN 0041-8811

E-ISSN 2665-0428

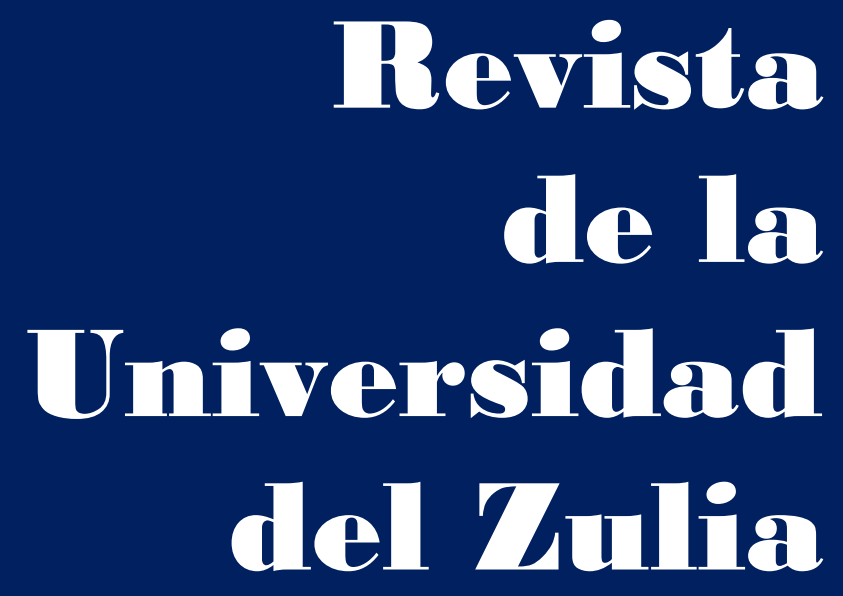

Fundada en 1947

por el Dr. Jesús Emrique Lossada

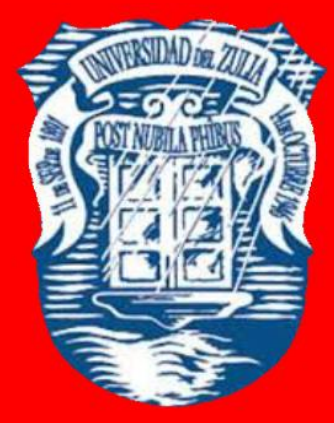

Ciencias

Sociales

y Arte

Año $12 \quad N^{\circ} 34$

Septiembre - Diciembre 2021

Tercera Época

Maracaibo-Veneruela 


\title{
Trafficking in persons: cluster analysis of sending and receiving countries
}

\author{
Yulia A. Siluyanova *
}

\begin{abstract}
The objective of this article is to deepen the understanding of the problem of human trafficking by analyzing the patterns of the distribution of traffic across countries, based on international statistics on various socio-economic indicators. We conducted cluster analysis using neuro network grouping algorithm of Kohonen self-organizing maps, basing on 44 variables reflecting different social and economical aspects for 144 countries. Countries were grouped according to the type and level of risk of trafficking-related crimes, and traffic distribution maps were built based on generally accepted hypotheses about traffic factors. As a result of the study, a number of hypotheses explaining the nature of traffic were tested. The results reveal the linkage between the risk of incoming and outgoing trafficking and the socio-economic parameters of the countries and groups.

KEY WORDS: human trafficking; slavery; exploitation; trafficking in persons; international crime; cluster analysis; Kohonen self-organizing maps; distribution maps; migration; Human Rights.
\end{abstract}

*PhD student, Lomonosov Moscow State University Moscow, Russia. ORCID: https://orcid.org/0000-0001-9752-0472. E-mail: zernovaju@gmail.com 


\section{Trata de personas: análisis por grupos temáticos de los países de origen y de acogida}

RESUMEN

El objetivo de este artículo es profundizar en la comprensión del problema de la trata de personas mediante el análisis de los patrones de distribución del tráfico entre países, sobre la base de estadísticas internacionales sobre diversos indicadores socioeconómicos. Se realizó un análisis de conglomerados utilizando el algoritmo de agrupación de redes neurológicas de los mapas autoorganizados de Kohonen, basándose en 44 variables que reflejan diferentes aspectos sociales y económicos para 144 países. Los países se agruparon según el tipo y el nivel de riesgo de delitos relacionados con la trata, y se construyeron mapas de distribución del tráfico basados en hipótesis generalmente aceptadas sobre los factores del tráfico. Como resultado del estudio, se probaron una serie de hipótesis que explicaban la naturaleza del tráfico. Los resultados revelan el vínculo entre el riesgo de tráfico entrante y saliente y los parámetros socioeconómicos de los países y grupos.

PALABRAS CLAVE: trata de personas, esclavitud, explotación, trata de personas, delincuencia internacional, análisis de conglomerados, mapas autoorganizados Kohonen, mapas de distribución, migración, Derechos Humanos.

\section{Introduction}

According to the estimates of international organizations, the number of victims of human trafficking around the world exceeds 40 million people at the moment, and the figure is steadily growing every year.

Trafficking, merging into migration flows, becomes almost invisible, which increases its latency, reduces risks for attackers and ensures the smooth operation of the criminal "conveyor" of the human trafficking industry. In the context of globalization, which has made the population more mobile and national borders more permeable, the profits of criminal structures from the sale and exploitation of "human goods" amount to more than 150 billion dollars a year (ILO says forced labour generates annual profits of US $\$ 150$ billion (ILO says forced labour generates annual profits of US\$ 150 billion, 2014).

This figure is comparable to the budgets of countries such as Finland and Saudi Arabia. At the same time, the most vulnerable in the face of the threat are representatives of the most unprotected social groups: orphans, the poor, people from disadvantaged families, the disabled, women, children, the elderly. 
REVISTA DE LA UNIVERSIDAD DEL ZULIA. 3época. Año $12 \mathrm{~N}^{\circ}$ 34, 2021

Yulia A. Siluyanova // Trafficking in persons: cluster analysis of sending and receiving countries, 317-340

DOI: http://dx.doi.org/10.46925//rdluz.34.19

Despite the attempts of the international scientific community to study the origins of the problem, the creation of international analytical institutions dedicated to the study of the phenomenon of trafficking in persons, the number of registered cases of this kind of crime is growing every year. This may mean that the number of victims is indeed increasing, and the ability to identify them is growing in the world.

Researchers are faced with the task of systematizing the available data on traffic, generalizing them and building such analytical models. Reliable assessment and analytics of trafficking processes are key to validating the theories on which the scientific community relies today. Having studied the phenomenon of trafficking, it is possible to reach a new level of understanding of the problem of trafficking in persons and formulate useful recommendations for combating trafficking in persons for state and non-state structures.

Due to the descriptive approach to the problem, there is still no generally accepted established explanation for this phenomenon. An analysis of scientific literature has shown that ideas about its nature are very different.

It should be noted that the problem of trafficking in the scientific community is relatively new and complex theories that fully reflect its causes, preconditions and patterns have not been developed to date. Trafficking is often considered within the framework of one of the scientific disciplines, such as law and forensics. Moreover, the phenomenon itself requires an interdisciplinary study, since it has deep social, cultural and anthropological roots.

Many researchers from the scientific community are trying to explain and predict the dynamics of the development of these processes. The same task is facing the governing bodies of states and international organizations. A serious problem for researchers is the lack of reliable empirical data and analytical models based on such data and allowing them to make validated informed assumptions about the patterns of trafficking.

In this paper, we attempt to deepen our understanding of the problem by examining the patterns of distribution of countries by the level and nature of trafficking. By grouping countries with similar trafficking crime situations, we can assess socioeconomic markers that indicate risk groups.

The problem of the lack of orderly reliable sources describing the situation with human trafficking is still urgent. Researchers and international experts are forced to rely on 
REVISTA DE LA UNIVERSIDAD DEL ZULIA. 3época. Año $12 \mathrm{~N}^{\circ}$ 34, 2021

Yulia A. Siluyanova // Trafficking in persons: cluster analysis of sending and receiving countries, 317-340 DOI: http://dx.doi.org/10.46925//rdluz.34.19

estimates of varying degrees of reliability in their work. The empirical data used by researchers is either fragmentary and has many gaps, or is judgmental, subjective.

Thus, we can use existing comparable databases with low confidence, or relatively reliable empirical data that are too narrow and local to draw general conclusions and not comparable with each other.

The objective of this article is to deepen the understanding of the problem of human trafficking by analyzing the patterns of the distribution of traffic across countries, based on international statistics on various socio-economic indicators. We have concentrated on those data, information about which is homogeneous, comparable and comes from reliable sources. In our case, these are data from the UN and other international organizations, or large transnational NGOs.

\section{Methodological aspects}

We included 44 variables in the study, reflecting various social, economic, demographic, cultural and other indicators. Here is a complete list with explanations.

\subsection{Trafficking and slavery}

Global Slavery Index (slavesTotal). The absolute number of victims in exploitation, according to the Global Slavery Index for 2018 (Global Slavery Index 2018, 2018).

Population in slavery per 1000 (SlavesPer1000). The number of victims of exploitation per 1000 population, according to the Global Slavery Index for 2018 (Global Slavery Index 2018, 2018).

Country of exploitation (inExpl). Ranking estimate of the volume of exploitation according to the CTDC portal of the International Organization for Migration, 2018. The indicator is ranged from 1 to 5, where 1 corresponds to the flow of less than 10 victims, 2 from 10 to 220, 3 - from 220 to 930, 4 - from 930 to 5600, 5 - more than 5600 (International Organization for Migration, 2019). This variable reflects the level of exploitation in the country and includes the incoming traffic flow; in the course of the study, we will consider it as an exploitation factor.

Country of origin (sourceCountry). Ranking of outbound traffic according to the CTDC portal of the International Organization for Migration, 2018. The indicator is ranged from 1 to 5, where 1 corresponds to the flow of less than 10 victims, 2 - from 10 to 220, 3 - from 
REVISTA DE LA UNIVERSIDAD DEL ZULIA. 3época. Año $12 \mathrm{~N}^{\circ}$ 34, 2021

Yulia A. Siluyanova // Trafficking in persons: cluster analysis of sending and receiving countries, 317-340 DOI: http://dx.doi.org/10.46925//rdluz.34.19

220 to 930,4 - from 930 to 5600, 5 - more than 5600 (International Organization for Migration, 2019). This variable reflects the origin of the victims of trafficking identified in different countries.

K trafficking. Generalized traffic ratio based on statistics from the CTDC portal of the International Organization for Migration. Calculated as the sum of the squares of the previous two variables.

Google HT. The volume of mentions in the Google news aggregator for the search query "human trafficking" per year.

\subsection{Demography}

Population. The absolute indicator of the number of population in the country according to the UN data for 2016 (Population data, 2019).

Birth rate. Birth rate - per 1000 people (Birth rate, crude (per 1,000 people), 2019).

Fertility rate. Special fertility rate (per woman) (Fertility rate, total (births per woman), 2019).

Adolescent fertility rate. Adolescent fertility is the number of births per 1000 women aged 15-19 years (Adolescent fertility rate (births per 1,000 women ages 15-19), 2019).

Death rate. Mortality rate per 1000 people (Death rate, crude (per 1,000 people), 2019).

Life expectancy at birth. Life expectancy at birth (Life expectancy at birth, total (years), 2019).

Population growth. Population growth for the year in percent (Population growth (annual \%), 2019).

Population ages 65 and above. The proportion of the country's population aged 65 and over, expressed as a percentage of the total population (Population ages 65 and above, total, 2019).

Population ages $0-14$. The proportion of the country's population between the ages of 0 and 14, expressed as a percentage of the total population (Population ages 0-14 (\% of total population), 2019).

\subsection{Migration}

International migrant stock. The number of international migrants in the country as a percentage of the total population of the state (International migrant stock (\% of 
population), 2019). This indicator is calculated on the basis of population censuses and includes people living in the country, but born in another state. In the absence of data, the UN independently estimates the indicator.

Refugees Azyl. The absolute number of refugees who arrived in the country (Refugee population by country or territory of asylum, 2019).

Refugees Orig. The absolute number of refugees who left the country (Refugee population by country or territory of origin, 2019).

Status Azyl pending. Number of pending applications for asylum or refugee status (Mid-Year Trends 2017, 2017).

Migrant remittance inflow. Total amount of migrant remittances in millions of US dollars from other countries during the year.

Migrant remittance outflow. Total amount in millions of US dollars sent by migrants via remittances to other countries (Migration and Remittances Data, 2019).

Mobile cellular subscriptions. The number of new mobile connections per 100 people per year (Mobile cellular subscriptions (per 100 people), 2019).

\subsection{Economy}

Adjusted net national income. Net national income per capita in US dollars (NPI) (Adjusted net national income per capita (current US\$, 2019).

Unemployment. Unemployment as a percentage of the total labor force (Unemployment, total (\% of total labor force) (modeled ILO estimate), 2019).

Employment 15-24. Employment among young people aged 15 to 24 years (Employment to population ratio, ages 15-24, total (\%)(modeled ILO estimate), 2019).

Inflation. Inflation is the GDP deflator index in percent per year (Inflation, GDP deflator (annual \%), 2019).

Natural resources rents. The share of revenues received by the government from natural resources, expressed as a percentage of GDP (Total natural resources rents (\% of GDP), 2019).

\subsection{Inequality}

GINI index. Gini coefficient, reflecting economic inequality in society (GINI index (World Bank estimate), 2019). 
REVISTA DE LA UNIVERSIDAD DEL ZULIA. 3época. Año $12 \mathrm{~N}^{\circ}$ 34, 2021

Yulia A. Siluyanova // Trafficking in persons: cluster analysis of sending and receiving countries, 317-340 DOI: http://dx.doi.org/10.46925//rdluz.34.19

Gender Inequality Index. Gender Inequality Index. This indicator was introduced by the UN to quantify gender discrimination (Gender Inequality Index, 2019).

Women in parliament. The proportion of seats in the country's parliament occupied by women (Proportion of seats held by women in national parliaments (\%), 2019).

\subsection{Conflicts}

Global Peace index. The Global Peace Index reflects the level of security in a country or region, taking into account different types of crime, internal and external conflicts, terrorist threats, arms sales, etc. The countries with the lowest index are the safest to live in (Global Peace Index, 2019).

Battle-related deaths. The number of deaths during armed conflicts (Battle-related deaths (number of people), 2019).

\subsection{Education, healthcare, ecology, culture and other}

Corruption. Corruption perception index, which reflects the abuse of authority by civil servants. It is measured on a scale from 100 (no corruption) to 0 (very high level of corruption) (Corruption Perceptions Index, 2019).

Gov expenditure on education. Government spending on education, expressed as a percentage of GDP (Government expenditure on education, total (\% of GDP), 2019).

Literacy. Literacy as a percentage of the total population (Literacy rate, 2019).

Secondary education. Population over 25 years old with at least secondary education, as a percentage of the total population (Key charts on Education, 2019).

Tuberculosis. The incidence of tuberculosis per 100,000 people (Incidence of tuberculosis (per 100,000 people), 2019).

Undernourishment. Percentage of the population at risk of hunger (Prevalence of undernourishment ( $\%$ of population), 2019).

Rural population. The rural population is the percentage of the country's population living in rural areas (Rural population (\% of total population), 2019).

Forest area. Forest area in the country (List of countries by forest area, 2019).

UNESCO. The number of UNESCO heritage sites in the country (UNESCO World Heritage Centre, 2019). 
REVISTA DE LA UNIVERSIDAD DEL ZULIA. 3época. Año $12 \mathrm{~N}^{\circ}$ 34, 2021

Yulia A. Siluyanova // Trafficking in persons: cluster analysis of sending and receiving countries, 317-340

DOI: http://dx.doi.org/10.46925//rdluz.34.19

Happiness Index. International index of happiness, which measures people's satisfaction with their living conditions, including income, prospects, environmental situation, etc. (World Happiness Report 2018, 2018).

Freedom to make life choices. Freedom of choice. One of the variables included in the happiness index. This is the average of the responses to the question "Are you satisfied with the freedom to choose what you do with your life?"

Social support. Social support (or having someone to count on in a difficult situation) is also one of the variables in the Happiness Index. This is the average of the binary responses (0 or 1 ) to the question "If you are in trouble, do you have any family or friends you can count on?"

In order to form a picture of the distribution of traffic in the modern world based on the listed data, we use cluster analysis. The algorithm that we use for classification in our model is self-organizing Kohonen maps. The result of his work is graphic maps, where each point represents one observation in the sample and has coordinates strictly defined by the network.

\section{Results and discussion}

The analysis is supposed to undercover some important trends of trafficking flows, understanding that human trafficking is a complex phenomenon, having multiple economic and social causes (Siluyanova, 2019). In our work we will verify some suggestions about trafficking, offered by researchers. So, Lanier and Henry (Lanier, Henry 2004) argue that traffic is determined by the theory of rational choice conclude that the choice of victims is not determined by any certain laws, but is carried out situationally. Cameron and Newman, divide the factors influencing traffic into two groups: structural and direct (Cameron, Newman 2008). Louise Shelley identifies demographic parameters, such as population growth, as an important prerequisite for traffic, as well as the reduction of the rural population by moving people to cities or abroad (Shelley 2010). In addition, gender inequality and discrimination are important factors in shaping trafficking flows, as noted by Kara Siddarth (Siddharth, 2009). Alexis Arnowitz claims that all migratory flows, including human trafficking, have the same causes (Aronowitz 2009).

We took the variables reflecting the absolute number of victims of exploitation from the Global Slavery Index database. We also have statistics on the number of registered cases 
of exploitation, which are kept by international institutions. As expected, these indicators should correlate with each other, since they are different measures of the same phenomenon. However, there is no relationship between these variables: the correlation coefficient of the inExpl and slavesPerl000 variables is -0.09. Since inExpl is an ordinal variable, we also checked Spearman's nonparametric correlation, however, no dependence was found: the coefficient was -0.08 .

The absence of any statistically significant correlation between the two datasets reflecting the level of trafficking indicates that, most likely, one of the variables does not correctly reflect the essence of the phenomenon under study, and we need to choose the one that is more representative. Since the statistics of actual registered cases recorded by international institutions seem to be more representative than the estimated value published by the NGO, we used the inExpl variable as a measure of the level of exploitation, and the sourceCountry variable to measure outgoing traffic.

Already at this stage, we can be convinced that the empirical base hides in itself many contradictions and difficulties. This result of comparing data from international institutions and NGOs indicates a low degree of measurement of the problem. This result also confirms fears that NGO statistics are of unclear origin and distort the overall picture.

First, let's build maps for the level of exploitation in the country (inExpl). To do this, we divide the data into five groups (Figure 1):

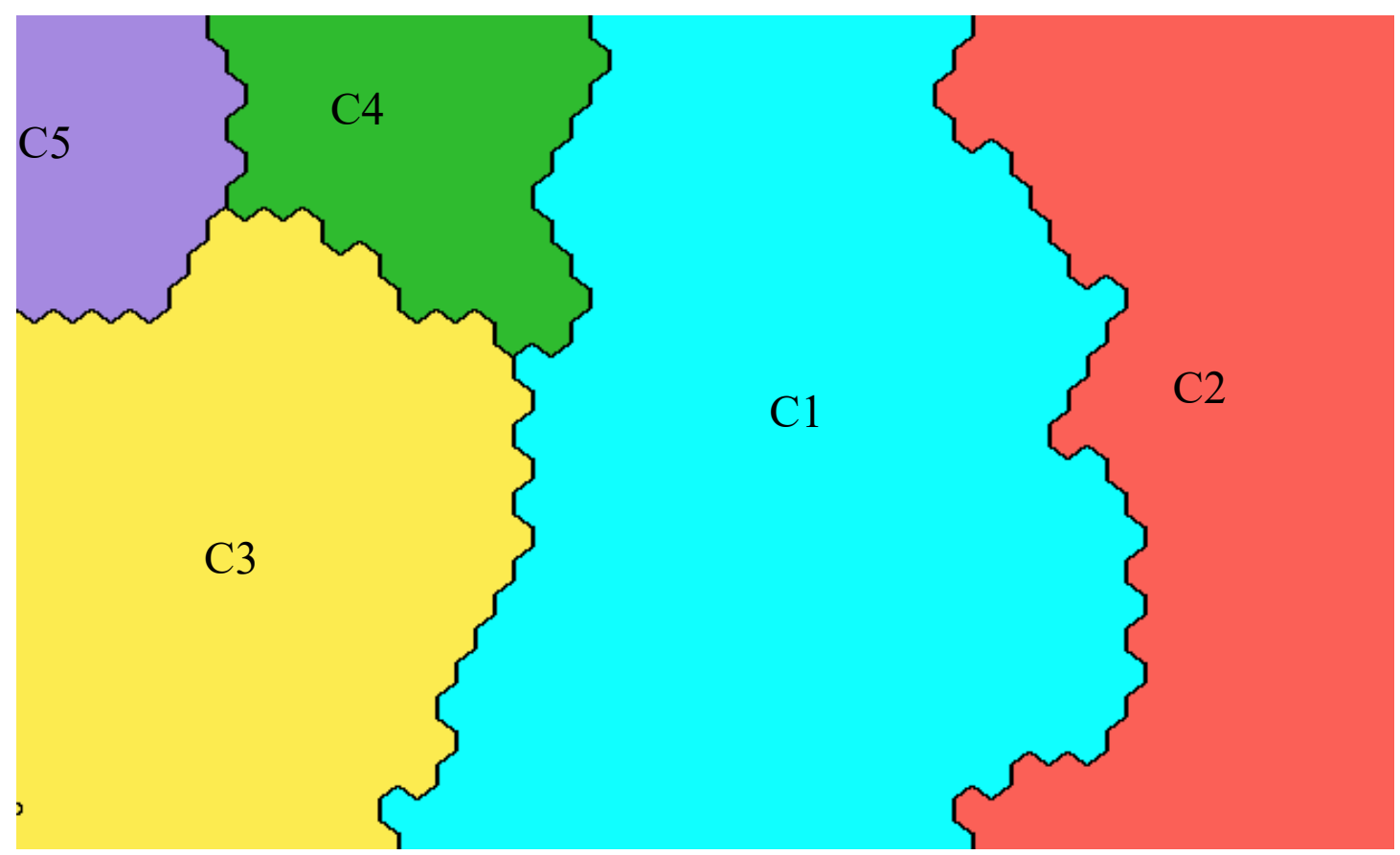

Figure 1 - Map of clusters with grouping attribute inExpl 
REVISTA DE LA UNIVERSIDAD DEL ZULIA. 3época. Año $12 \mathrm{~N}^{\circ}$ 34, 2021

Yulia A. Siluyanova // Trafficking in persons: cluster analysis of sending and receiving countries, 317-340 DOI: http://dx.doi.org/10.46925//rdluz.34.19

In the figure, each point is a sample country. The stronger the countries are similar to each other in terms of a set of features, the closer they are displayed on the map. The points farthest from each other, respectively, have the maximum degree of difference.

First of all, we consider the statistics of clusters (table l) and give a description of each group. For convenience, all indicators in the table are highlighted in colors: green indicates the lowest values, orange indicates the highest values.

Table 1 - Table of average values of clusters with the grouping attribute inExpl

\begin{tabular}{|l|r|r|r|r|r|r|r|}
\hline Cluster & CountrExpl & RemitOut & \multicolumn{1}{|c|}{ NetInc } & Corruption & Pop65+ & Pop0-14 & Fertility \\
\hline C 1 & 1,896 & 1015 & 4662 & 33,23 & 6,79 & 27,22 & 2,344 \\
\hline C 2 & 1,524 & 179 & 1156 & 30 & 3,1 & 41,84 & 4,638 \\
\hline C 3 & 2,108 & 4327 & 23635 & 63,14 & 17,05 & 16,6 & 1,635 \\
\hline C 4 & 4 & 11924 & 11532 & 44,67 & 12,99 & 18,28 & 1,75 \\
\hline C 5 & 2,75 & 15552 & 21408 & 47,25 & 2,97 & 22,19 & 2,277 \\
\hline & & & & & $\begin{array}{c}\text { Int } \\
\text { migrant } \\
\text { stock }\end{array}$ & \\
& $\begin{array}{r}\text { secEduc } \\
\text { 25+ }\end{array}$ & Literacy & Undernourish & Happiness & Rural pop \\
\hline C 1 & 61,9 & 97,2 & 8,22 & 5,353 & 42,46 & 2,47 & 3,35 \\
\hline C 2 & 33,8 & 72,8 & 23,72 & 4,129 & 60,59 & 2,83 & 3,9 \\
\hline C 3 & 89,2 & 99,7 & 2,96 & 6,246 & 27,19 & 11,1 & 1,41 \\
\hline C 4 & 92,9 & 99,5 & 2,32 & 5,881 & 33,86 & 7,79 & 4,7 \\
\hline C 5 & 65,1 & 99,2 & 5,04 & 6,128 & 10,44 & 54,65 & $-13,08$ \\
\hline & & & & & & Death & Life \\
& Mobile & Tuberculosis & GINI & GenInequality & Unemployment & rate & exp \\
\hline C 1 & 112,4 & 100 & 40,98 & 0,3985 & 7,13 & 6,42 & 72,91 \\
\hline C 2 & 77,8 & 238,2 & 42,26 & 0,5788 & 7,72 & 8,87 & 61,04 \\
\hline C 3 & 123,7 & 16 & 32,45 & 0,1218 & 10,96 & 9,76 & 79,57 \\
\hline C 4 & 126,2 & 52 & 33,79 & 0,2163 & 4,74 & 10,82 & 74,4 \\
\hline C 5 & 149,2 & 12,7 & 31,31 & 0,2836 & 4,26 & 2,83 & 76,41 \\
\hline Compiled by the author & & & & & \\
\hline
\end{tabular}

Cluster $1(\mathrm{Cl})-33.3 \%$ of observations. This group of countries has a low per capita income, average inflation and a fairly high unemployment rate. The birth and death rates are average here, there are many children in the structure of the population, and the share of the rural population is quite high. There are few migrants in these countries, high morbidity, economic and gender inequality, and the level of corruption.

Cluster 2 (C2) - 29\% of observations. It has the lowest NPI, high unemployment, high inflation and the highest risk of hunger. These countries have record high mortality and 
fertility, many children, the lowest life expectancy, few migrants, the highest morbidity, very low literacy and education levels, strong corruption, the worst indicators of all variables reflecting the observance of human rights.

Cluster 3 (C3) - 26\% of observations. This is almost the complete opposite of the previous "dysfunctional" cluster: High NPI, low corruption, excellent indicators of the index of happiness and equality, low morbidity, low birth rate, high mortality, many migrants (Siluyanova, 2019).

Cluster 4 (C4) - $6 \%$ of observations. These countries show an average NPI, relatively high inflation rates, and low unemployment. The birth rate here is low, and the mortality rate is very high. There are a lot of children and the elderly in the population structure, the average number of migrants, average indicators of corruption, happiness, inequality, high literacy and a high rate of remittances of migrants abroad.

Cluster 5 (C5) - 6\% of observations. Typical features are a high NPI, low unemployment, and no inflation. This is the average birth rate, very low mortality, high life expectancy, very few old people and a lot of migrants. At the same time, the indices of happiness and inequality are average, or high and a record indicator of outgoing remittances of migrants.

We identified two "prosperous" groups, one group with dramatically poor performance, and two groups in between. The map we have built perfectly reproduces the geopolitical concept of dividing countries into developed, transitional and third world countries. One of these concepts - world-systems analysis - suggests dividing the worldsystem into core, periphery and semi-periphery with properties very similar to the identified properties of clusters. Thus, "safe" clusters (C5, C3) represent the core, "dysfunctional" (C2) - the periphery, and the layer $(\mathrm{Cl})$ - semi-periphery. We are even more convinced of the similarity of the classification with the world-system interpretation by examining the lists of clusters (Table 2).

The prosperous clusters included the European states and Canada (C3) and the countries of the Middle East (C5). The disadvantaged cluster is the countries of Africa. "Interlayer" $(\mathrm{Cl})$ - Asian and Latin American countries.

Next comes the most important part of this stage of the analysis; this is an examination of the map of the distribution of individual variables (Figure 3). 


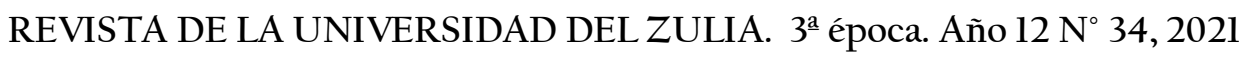

Yulia A. Siluyanova // Trafficking in persons: cluster analysis of sending and receiving countries, 317-340

DOI: http://dx.doi.org/10.46925//rdluz.34.19

Table 2 - List of countries included in clusters with grouping attribute inExpl

\begin{tabular}{|c|c|c|c|c|}
\hline $\mathrm{Cl}$ & $\mathrm{C} 2$ & C3 & $\mathrm{C} 4$ & C5 \\
\hline Turkey & Uganda & Norway & United States & $\begin{array}{c}\text { United Arab } \\
\text { Emirates }\end{array}$ \\
\hline Philippines & Senegal & Macedonia & $\begin{array}{l}\text { Russian } \\
\text { Federation }\end{array}$ & Saudi Arabia \\
\hline Indonesia & Haiti & Japan & Poland & Qatar \\
\hline Cambodia & Ghana & Italy & Moldova & Lebanon \\
\hline Uzbekistan & Afghanistan & Czech Republic & Malaysia & Kuwait \\
\hline Thailand & Zambia & $\begin{array}{c}\text { Bosnia and } \\
\text { Herzegovina }\end{array}$ & Kazakhstan & Jordan \\
\hline Tajikistan & Yemen & Albania & Belarus & Oman \\
\hline South Africa & Sudan & United Kingdom & Romania & Bahrain \\
\hline Egypt & Sierra Leone & Switzerland & Bulgaria & \\
\hline China & Papua New Guinea & Sweden & & \\
\hline Vietnam & Pakistan & Spain & & \\
\hline Turkmenistan & Madagascar & Slovenia & & \\
\hline $\begin{array}{c}\text { Trinidad and } \\
\text { Tobago }\end{array}$ & Kenya & Slovakia & & \\
\hline $\begin{array}{l}\text { Syrian Arab } \\
\text { Republic }\end{array}$ & Ethiopia & Serbia & & \\
\hline Peru & Côte d'Ivoire & Portugal & & \\
\hline Morocco & Cameroon & Netherlands & & \\
\hline Mexico & Benin & Montenegro & & \\
\hline Mauritius & Zimbabwe & Lithuania & & \\
\hline Libya & Togo & Korea & & \\
\hline Kyrgyzstan & Tanzania, & Israel & & \\
\hline Iraq & South Sudan & Ireland & & \\
\hline Iran & Rwanda & Hungary & & \\
\hline Guatemala & Nigeria & Greece & & \\
\hline Ecuador & Niger & Germany & & \\
\hline $\begin{array}{c}\text { Dominican } \\
\text { Republic }\end{array}$ & Namibia & Georgia & & \\
\hline Colombia & Mozambique & France & & \\
\hline Bangladesh & Mongolia & Finland & & \\
\hline Azerbaijan & Mauritania & Denmark & & \\
\hline Argentina & Mali & Cyprus & & \\
\hline Venezuela & Malawi & Croatia & & \\
\hline Ukraine & Liberia & Belgium & & \\
\hline Tunisia & Lesotho & Austria & & \\
\hline Sri Lanka & Guinea-Bissau & Australia & & \\
\hline Paraguay & Gambia & Armenia & & \\
\hline Panama & Gabon & Uruguay & & \\
\hline Nicaragua & Congo & Latvia & & \\
\hline Nepal & Chad & Canada & & \\
\hline
\end{tabular}


REVISTA DE LA UNIVERSIDAD DEL ZULIA. $3^{a}$ época. Año $12 \mathrm{~N}^{\circ}$ 34, 2021

Yulia A. Siluyanova // Trafficking in persons: cluster analysis of sending and receiving countries, 317-340 DOI: http://dx.doi.org/10.46925//rdluz.34.19

\begin{tabular}{|c|c|l|l|l|} 
Myanmar & $\begin{array}{c}\text { Central African } \\
\text { Republic }\end{array}$ & & & \\
\hline Jamaica & Burundi & & & \\
\hline India & Burkina Faso & & & \\
\hline Honduras & Botswana & & & \\
\hline Guyana & Angola & & & \\
\hline Cuba & & & & \\
\hline Costa Rica & & & & \\
\hline Chile & & & & \\
\hline Brazil & & & & \\
\hline Bolivia & Algeria & & & \\
\hline \multicolumn{7}{|c|}{ Compiled by the author } & \\
\hline
\end{tabular}
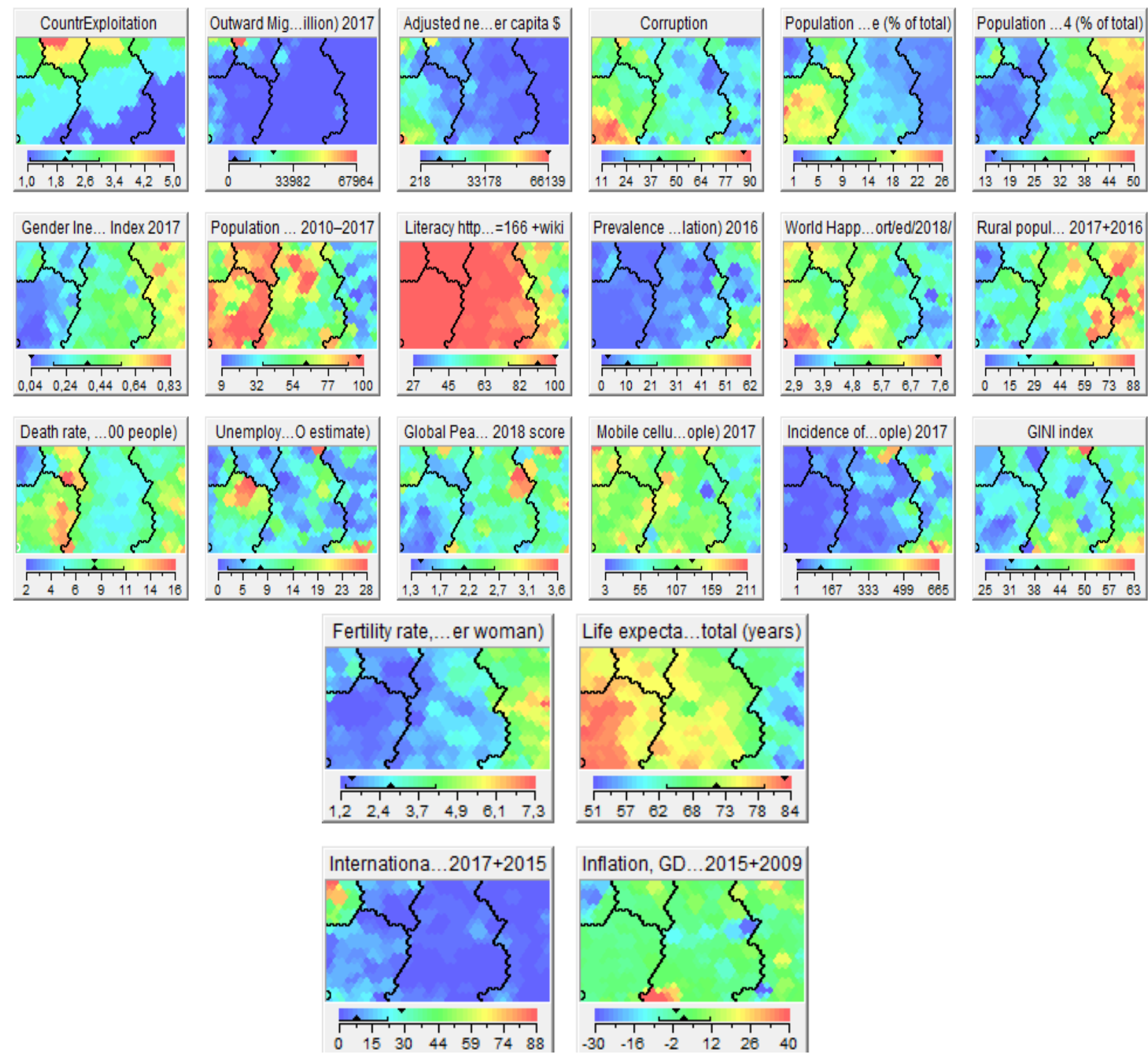

Figure 3 - Maps of variables with the boundaries of clusters with the grouping attribute inExpl 
Most of all, we will be interested in the first picture, which reflects the distribution of countries according to the level of exploitation. We clearly see that the C4 cluster was formed by countries where this problem is especially strong. Since the representatives of the cluster are heterogeneous in other parameters, the averaged statistics of average indicators does not describe it well enough. We also see that the second place in terms of exploitation is occupied by the Middle East cluster $\mathrm{C} 5$. In addition, in the cluster-interlayer $\mathrm{Cl}$, the contour of a subcluster with high exploitation rates is outlined. The main "marker" of a high utilization rate is the volume of outgoing money transfers.

Clusters completely free from the problem have not been formed; The lowest rate of exploitation, contrary to many theoretical models linking the level of trafficking with the level of development of civil and human rights institutions, is in the countries of the stratum cluster, where these institutions are not well developed. In those countries where the indices of equality and freedoms are high, also contrary to expert estimates, the level of exploitation is at its maximum. Thus, today developed civil institutions are unable to reduce the rates of trafficking. The general low level of social inequality also does not contribute to a decrease in exploitation; on the contrary, it is under a more equitable social system that exploitation is carried out more often.

Another important fact that we can observe on the maps: the lack of a constant relationship between trafficking and migration. If the correlation for the countries of the Middle East can be traced, then it is absent in the cluster of leaders in terms of exploitation: the number of migrants here is negligible. If we relate the flows of incoming migration to the level of traffic, then one would expect that the European cluster would become the leader; however, this does not happen and the hypothesis of a direct relationship between these phenomena must be rejected.

Another important conclusion that we can draw from distribution maps is the definition of the main "pivot points" of clustering, that is, the basic principles of difference. This can be done by examining the boundaries of the clusters. The variables that define them will be the most important. Such variables for inExpl include: the number of old people and children, life expectancy, literacy, rural population, general population, gender inequality. 
If we graphically display the clusters on the map, marking the highest risk of exploitation in red and the lowest in green, we get a map of the distribution of countries depending on the structure of the risk of exploitation (Figure 4).

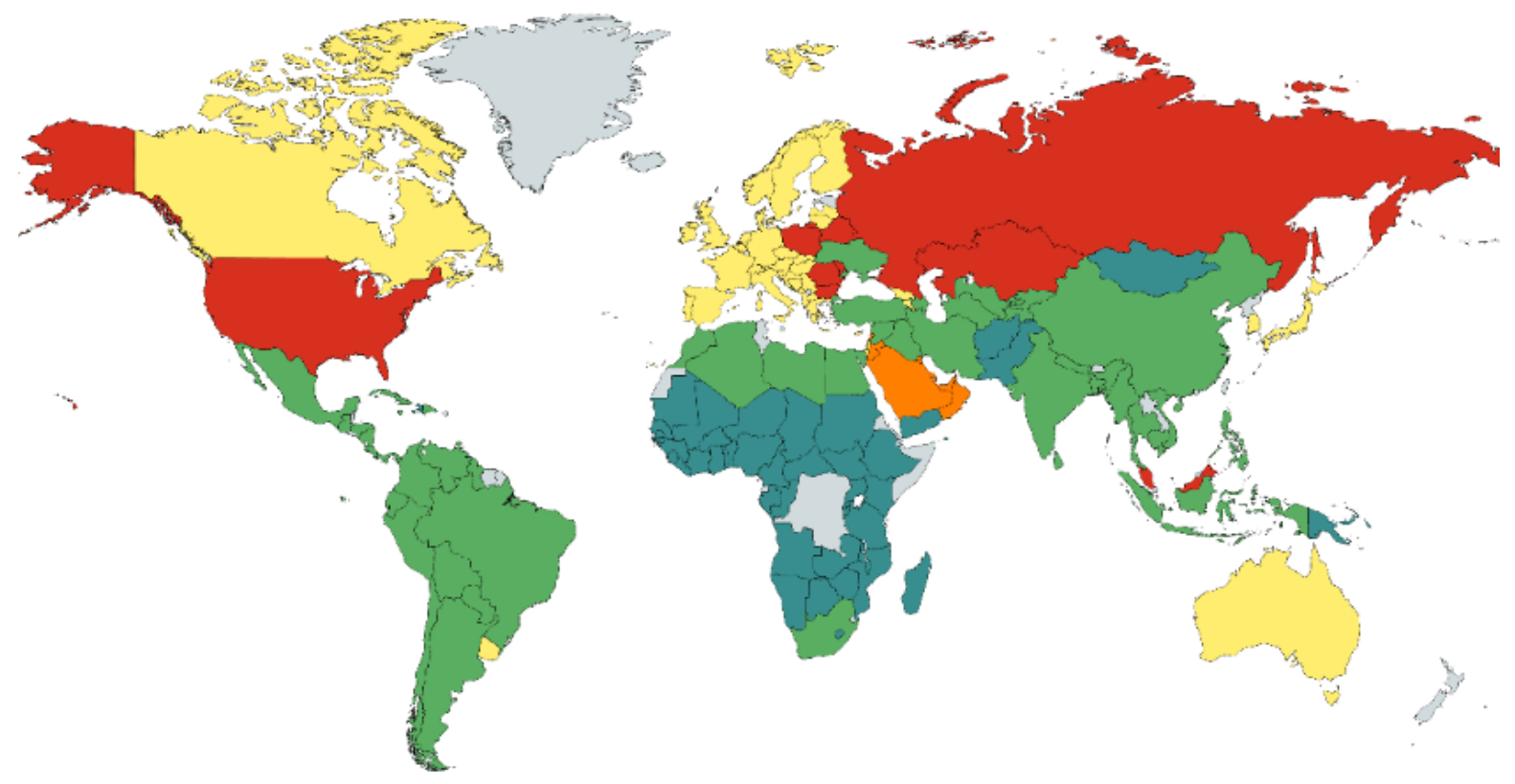

Figure 4 - Geographic distribution of countries by level of exploitation

Further, the indicator of outgoing traffic is analyzed in a similar way. Our task is to identify key donor countries and their properties. We divide all countries from the sample into 5 clusters (Figure 5).

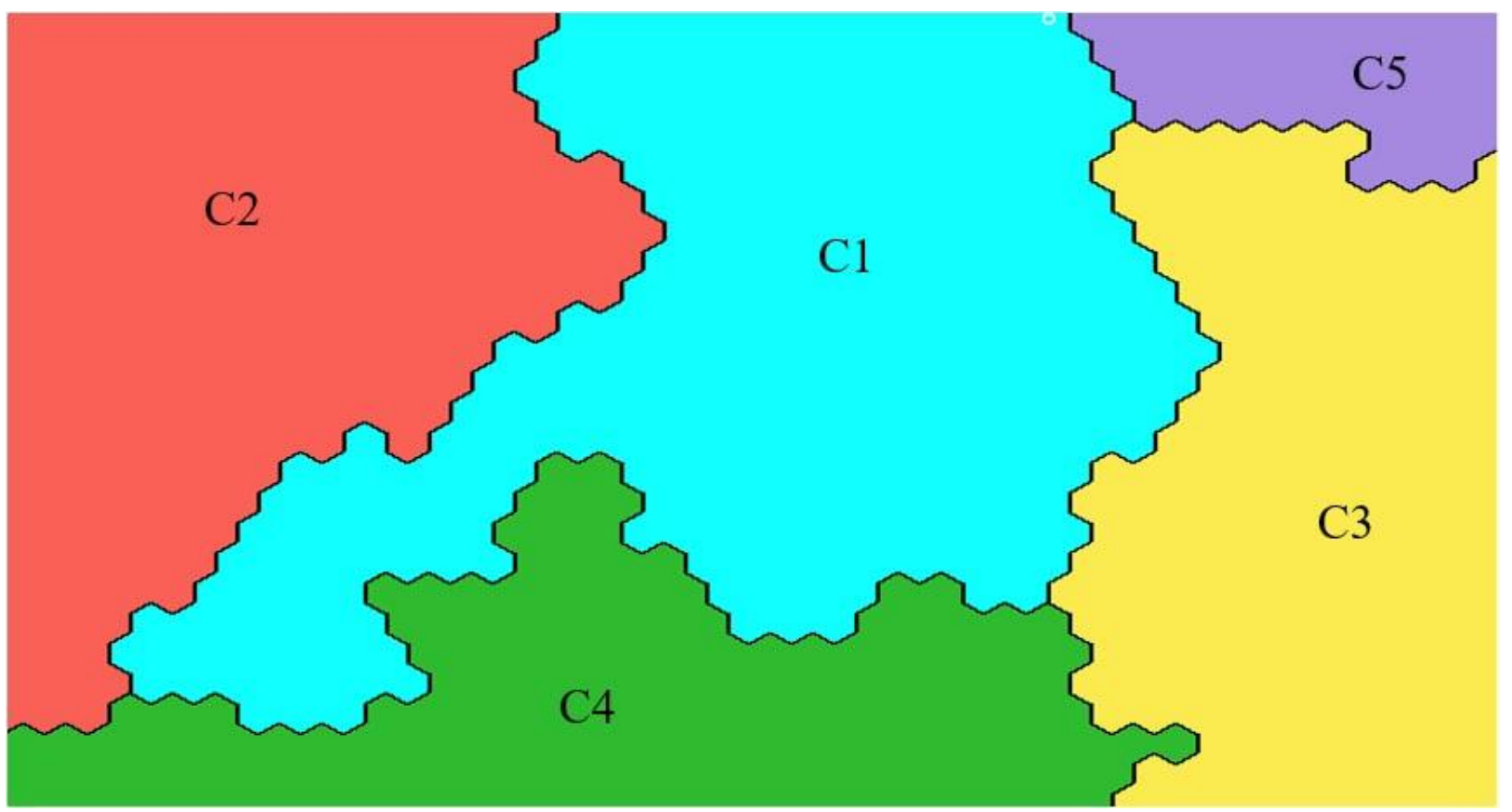

Figure 5 - Map of clusters with grouping attribute sourceCountry 


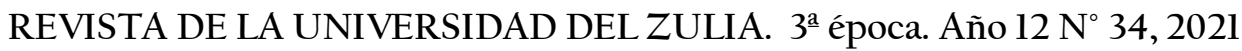

Yulia A. Siluyanova // Trafficking in persons: cluster analysis of sending and receiving countries, 317-340

DOI: http://dx.doi.org/10.46925//rdluz.34.19

Average indicators for clusters are presented in Table 3.

Table 3 - Table of average values of cluster variables with grouping attribute sourceCountry

\begin{tabular}{|c|c|c|c|c|c|c|c|c|}
\hline Cluster & Frequency & Origin & Inflation & $\begin{array}{l}\text { migrant } \\
\text { stock }\end{array}$ & $\begin{array}{l}\text { nat } \\
\text { income }\end{array}$ & Corruption & $\begin{array}{l}\text { Gender } \\
\text { Inequality }\end{array}$ & $\begin{array}{l}\text { Population } \\
0-14\end{array}$ \\
\hline $\mathrm{Cl}$ & $25,69 \%$ & 1,757 & 3,32 & 3,12 & 5404 & 38,51 & 0,4037 & 27,85 \\
\hline$C 2$ & $27,08 \%$ & 1,923 & 3,22 & 2,5 & 974 & 27,1 & 0,5908 & 42,52 \\
\hline C 3 & $24,31 \%$ & 1,543 & 1,14 & 11,27 & 24701 & 64,34 & 0,1121 & 16,32 \\
\hline C 4 & $17,36 \%$ & 3,6 & 5,23 & 4,41 & 5925 & 34,36 & 0,3193 & 23,32 \\
\hline \multirow[t]{2}{*}{ C 5} & $5,56 \%$ & 1 & $-13,08$ & 54,65 & 21408 & 47,25 & 0,2836 & 22,19 \\
\hline & $\begin{array}{l}\text { Fertility } \\
\text { rate }\end{array}$ & $\begin{array}{l}\text { Life } \\
\text { expectancy }\end{array}$ & Happiness & $\begin{array}{l}\text { Social } \\
\text { support }\end{array}$ & Literacy & $\begin{array}{l}\text { Adolescent } \\
\text { fertility }\end{array}$ & $\begin{array}{l}\text { Sec } \\
\text { education } \\
25+\end{array}$ & $\begin{array}{l}\text { Population } \\
65^{+}\end{array}$ \\
\hline $\mathrm{Cl}$ & 2,4 & 72,45 & 5,404 & 1,264 & 96,6 & 54,3 & 59,5 & 6,78 \\
\hline C 2 & 4,735 & 61,26 & 4,071 & 0,856 & 71,3 & 97,3 & 31,1 & 3,05 \\
\hline C 3 & 1,621 & 79,84 & 6,318 & 1,399 & 99,8 & 10,8 & 89,9 & 17,28 \\
\hline C 4 & 2,135 & 72,5 & 5,383 & 1,325 & 98,5 & 34 & 78,7 & 9,16 \\
\hline \multirow[t]{2}{*}{ C 5} & 2,277 & 76,41 & 6,128 & 1,228 & 99,2 & 14,5 & 65,1 & 2,97 \\
\hline & $\begin{array}{l}\text { Pop } \\
\text { growth }\end{array}$ & Undernourish & Tuberculosis & $\begin{array}{l}\text { Rural } \\
\text { pop }\end{array}$ & Mobile & Unemployment & $\begin{array}{l}\text { Remit } \\
\text { inflow }\end{array}$ & Death \\
\hline $\mathrm{Cl}$ & 1,2 & 8,98 & 124,1 & 35,3 & 114,5 & 9,38 & 2812 & 6,61 \\
\hline C 2 & 2,496 & 23,86 & 196,3 & 62,76 & 71,4 & 6,88 & 1657 & 8,76 \\
\hline C 3 & 0,281 & 2,85 & 15 & 27,42 & 123,3 & 10,56 & 3966 & 9,66 \\
\hline C 4 & 0,826 & 6,36 & 123,8 & 47,22 & 121,4 & 5,19 & 11193 & 8,61 \\
\hline C 5 & 3,564 & 5,04 & 12,7 & 10,44 & 149,2 & 4,26 & 1678 & 2,83 \\
\hline
\end{tabular}

Cluster $1(\mathrm{Cl})-26 \%$ of observations. This group has mainly average economic and demographic indicators, while there is a fairly high gender inequality, morbidity, unemployment, literacy, the number of migrants here is relatively small.

Cluster 2 (C2) - 27\% of observations. Average inflation and unemployment rates, low NPI are combined with very high rates of morbidity, corruption, threat of hunger, and inequality indices. It has the highest birth rate, relatively high mortality, high population growth, and short life expectancy. In all respects, this cluster resembles the "disadvantaged" countries from the previous stage of the analysis.

Cluster 3 (C3) - 24\% of observations. These countries are characterized by low inflation, high NPI, low fertility and population growth, a large number of migrants. It has the highest death and unemployment rates, the highest life expectancy, the highest level of happiness and the lowest level of corruption. 
Cluster 4 (C4) - 17\% of observations. In many respects, it has average indicators, stands out with a record high level of social support, the highest inflation, mortality is quite high here, there are quite a lot of elderly people, and low unemployment rates. This is where the largest flow of remittances from migrants comes from abroad.

Cluster 5 (C5) - $6 \%$ of observations. There is negative inflation, a huge number of migrants, high NPI and favorable social indicators.

Here again we see a division in accordance with the current geopolitical situation. Two "safe" clusters have emerged, one "dysfunctional" and a layer between them.

Further attention is paid to how the socio-economic statistics of different countries are distributed among groups. For this, the distribution graphs for each variable are considered (Figure 6).

The conventional wisdom is that we expect to see the highest traffic rate in the "dysfunctional" C2, but this is not happening. This cluster ranks second in terms of outbound traffic, while the leader is the "average" C4. It is this cluster that makes up the core of donor countries. We also observe a group with the lowest possible level of the indicator, that is, a cluster that is not actually engaged in the "export" of live goods. These are C5 - Middle Eastern oil economies, which are second in terms of exploitation. Cluster C3, that is, European countries, has a very low rate of outbound traffic.

In order to make sure that our assumptions about the composition of the clusters are correct, consider the results of the grouping (Table 4).

This time the grouping turned out to be less geographically accurate: the first cluster contains the countries of Latin America, Africa, and some Asian states. The second cluster is still almost entirely composed of African countries. The third and fifth clusters with industrialized developed economies as well as the oil powers of the Middle East have changed little. But cluster 4, which brought together the most problematic states, expanded.

It is noteworthy that the volume of remittances, this time incoming, again became a marker of high traffic.

Geographically distributing the clusters on the map, we obtain a scheme for the distribution of the risk of outgoing trafficking, where the most active donor countries are shown in red, and the countries with the lowest level are indicated in green (Figure 7). 


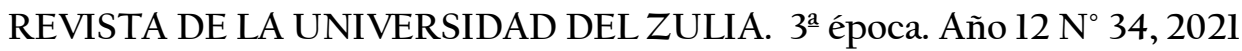

Yulia A. Siluyanova // Trafficking in persons: cluster analysis of sending and receiving countries, 317-340 DOI: http://dx.doi.org/10.46925//rdluz.34.19
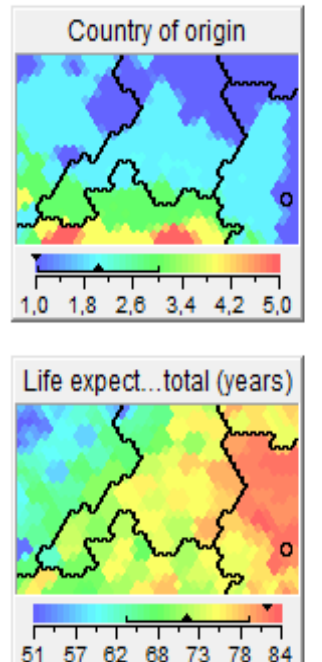

$\begin{array}{lllllll}51 & 57 & 62 & 68 & 73 & 78 & 84\end{array}$

Prevalence ...ation) 2016

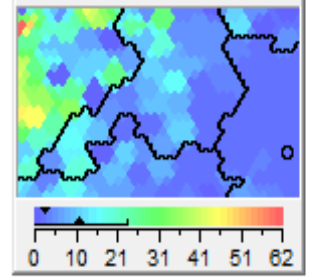

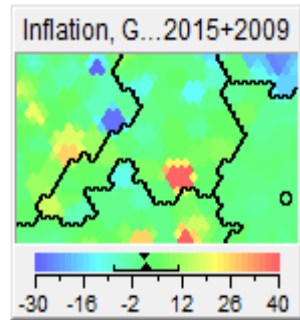

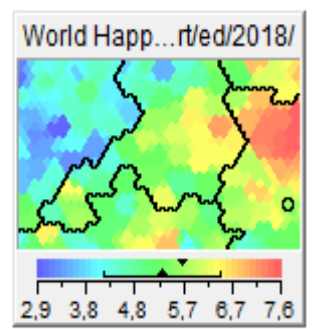

Incidence of...ople) 2017

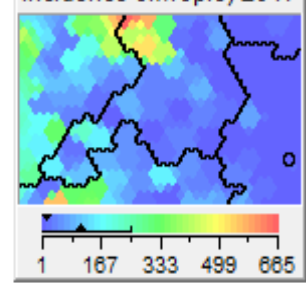

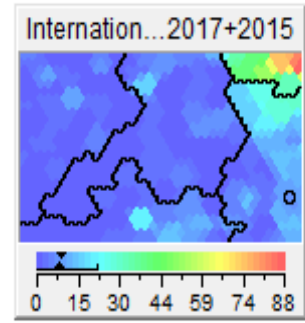

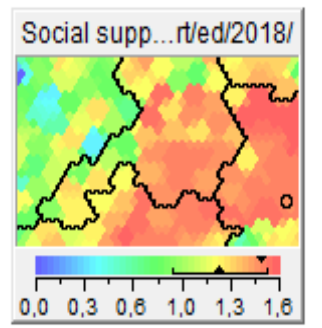

Rural popu...2017+2016

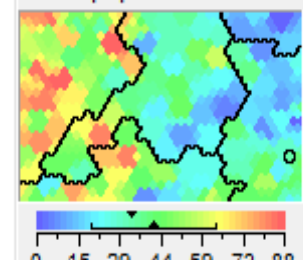

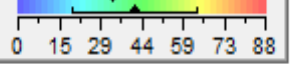
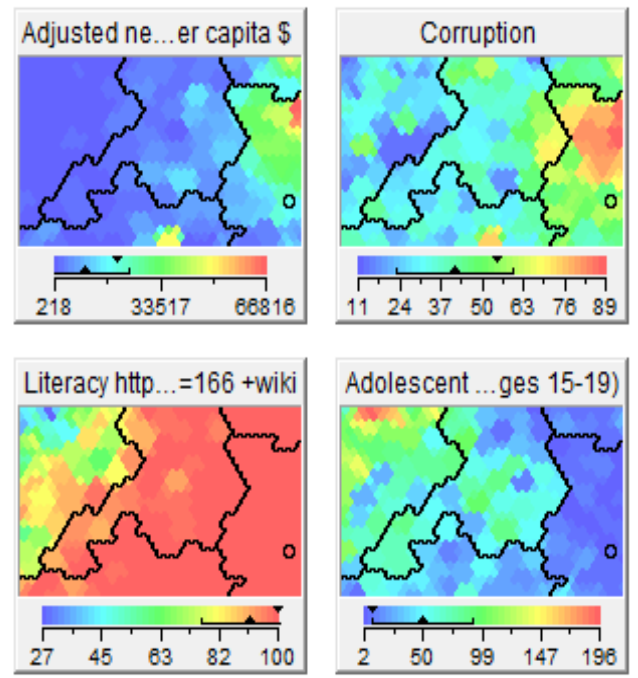

Mobile cellu...ople) 2017
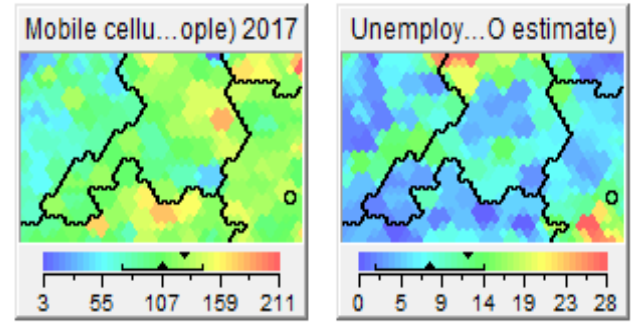
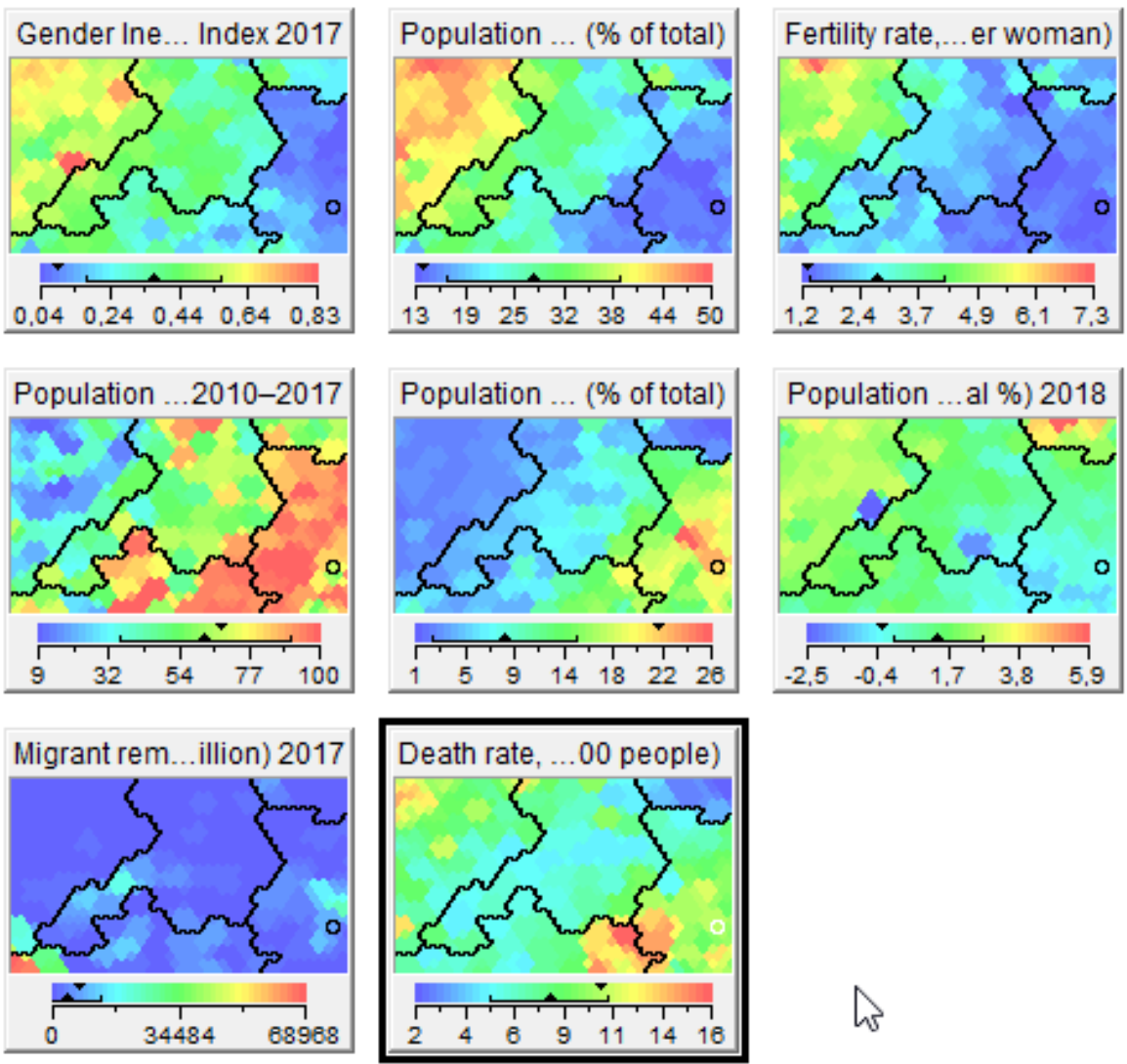

as

Figure 6 - Maps of distribution of variables in clusters with the grouping attribute sourceCountry 
REVISTA DE LA UNIVERSIDAD DEL ZULIA. 3e época. Año $12 \mathrm{~N}^{\circ}$ 34, 2021

Yulia A. Siluyanova // Trafficking in persons: cluster analysis of sending and receiving countries, 317-340

DOI: http://dx.doi.org/10.46925//rdluz.34.19

Table 4 - Countries included in clusters with grouping attribute sourceCountry

\begin{tabular}{|c|c|c|c|c|}
\hline $\mathrm{Cl}$ & C2 & C3 & C4 & C5 \\
\hline Honduras & Nigeria & Albania & United States & $\begin{array}{c}\text { United Arab } \\
\text { Emirates }\end{array}$ \\
\hline Guatemala & Uganda & United Kingdom & Ukraine & Saudi Arabia \\
\hline Ghana & Haiti & Spain & Philippines & Qatar \\
\hline Colombia & Ethiopia & Slovakia & Cambodia & Oman \\
\hline Bolivia & Afghanistan & Poland & Uzbekistan & Lebanon \\
\hline Venezuela & Zimbabwe & Netherlands & Romania & Kuwait \\
\hline Uruguay & Zambia & Macedonia & Myanmar & Jordan \\
\hline Turkey & Togo & Lithuania & Moldova & Bahrain \\
\hline South Africa & Tanzania, & Latvia & Mexico & \\
\hline Peru & Syrian Arab Republic & Rep, of Korea & Kyrgyzstan & \\
\hline Paraguay & Sudan & Japan & Indonesia & \\
\hline Nicaragua & Sierra Leone & Hungary & Belarus & \\
\hline Nepal & Senegal & Germany & Argentina & \\
\hline Morocco & Rwanda & Georgia & Vietnam & \\
\hline Mongolia & Pakistan & Czech Republic & Turkmenistan & \\
\hline Malaysia & Niger & Canada & Thailand & \\
\hline Jamaica & Mozambique & $\begin{array}{c}\text { Bosnia and } \\
\text { Herzegovina }\end{array}$ & Tajikistan & \\
\hline Egypt & Mali & Australia & Sri Lanka & \\
\hline Ecuador & Malawi & Switzerland & Serbia & \\
\hline $\begin{array}{c}\text { Dominican } \\
\text { Republic }\end{array}$ & Madagascar & Sweden & $\begin{array}{c}\text { Russian } \\
\text { Federation }\end{array}$ & \\
\hline Cuba & Liberia & Slovenia & Kazakhstan & \\
\hline Brazil & Kenya & Portugal & China & \\
\hline Bangladesh & Guinea-Bissau & Norway & Bulgaria & \\
\hline Tunisia & Gambia & Montenegro & India & \\
\hline $\begin{array}{c}\text { Trinidad and } \\
\text { Tobago } \\
\end{array}$ & Congo & Italy & Azerbaijan & \\
\hline Panama & Côte d'Ivoire & Israel & & \\
\hline Namibia & Cameroon & Ireland & & \\
\hline Mauritius & Burundi & Greece & & \\
\hline Libya & Burkina Faso & France & & \\
\hline Lesotho & Benin & Finland & & \\
\hline Iran & Yemen & Denmark & & \\
\hline Gabon & South Sudan & Cyprus & & \\
\hline Costa Rica & Papua New Guinea & Croatia & & \\
\hline Chile & Mauritania & Belgium & & \\
\hline Botswana & Iraq & Austria & & \\
\hline Armenia & Guyana & & & \\
\hline Algeria & Chad & & & \\
\hline & Central African Republic & & & \\
\hline & Angola & & & \\
\hline \multicolumn{5}{|c|}{ Compiled by the author } \\
\hline
\end{tabular}




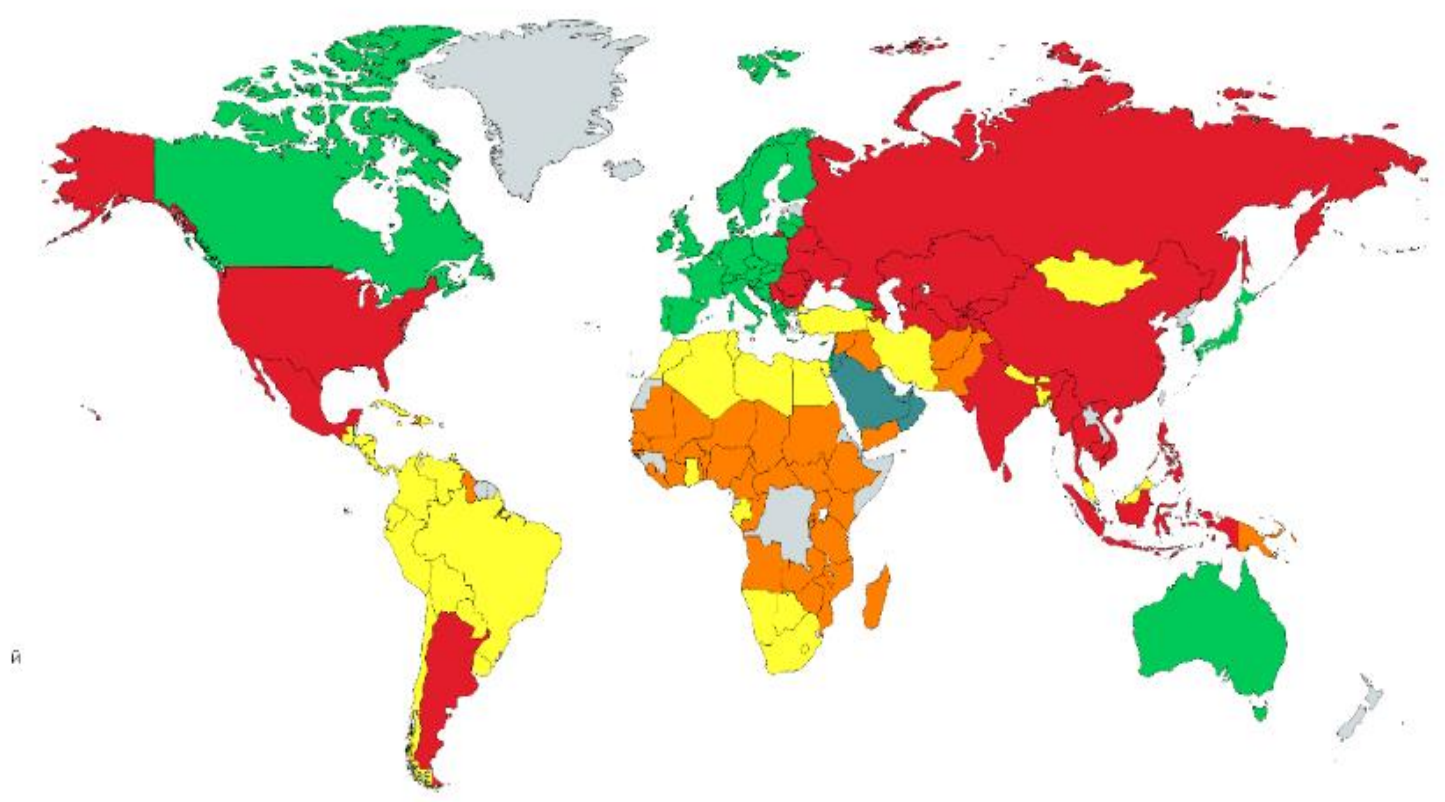

Figure 7 - Geographic distribution of countries by the level of outgoing traffic

The analysis shows, that grouping the countries we can clearly see some important trends, describing the nature of human trafficking.

\section{Conclusion}

Analyzing the level of trafficking in different countries, we made sure that countries can be conditionally divided into donor countries and destination countries. The analysis shows that there are features in common that can indicate the countries with a high potential risk of incoming and outgoing trafficking. Existing theories are often controversial, they need more data to clearly describe the phenomenon of trafficking. Meanwhile, the study shows that trafficking flows are formed according to common principles, which means that they are pore ore less determined and can be predicted.

In order to deepen our understanding of the trafficking industry, it is also important to build an empirical base. The collection, systematization and generalization of information about crimes related to trafficking makes it possible to create qualitatively new databases and more reliable mathematical models. Today, the Russian and world scientific community is experiencing difficulties in studying the topic of human trafficking, primarily because of the lack of high-quality empirical data. As the information base develops, prospects for a comprehensive interdisciplinary study of the problem of trafficking open up, to which 
REVISTA DE LA UNIVERSIDAD DEL ZULIA. 3época. Año $12 \mathrm{~N}^{\circ}$ 34, 2021

Yulia A. Siluyanova // Trafficking in persons: cluster analysis of sending and receiving countries, 317-340 DOI: http://dx.doi.org/10.46925//rdluz.34.19

economists, psychologists, sociologists, political scientists and representatives of other social sciences can connect.

Having studied the patterns, we have reason to argue that in the modern world, many of the tools used by national governments to combat human trafficking are not effective enough. Thus, neither the tightening of migration controls, nor the restrictions on migration are able to solve the problem of trafficking in the context of globalization, since it is a more complex phenomenon, and the traffic flow is formed according to completely different patterns than the migration flow.

Thus, the anti-trafficking policy should, first of all, be based on a clear understanding of this phenomenon, work with social groups at greatest risk, raise the awareness of society and government structures about the problem of human trafficking, and develop a clear comprehensive strategy for the prevention and investigation of this type of crime.

\section{Acknowledgments}

The study was carried out with the financial support of RFFI as part of the scientific project No. 19-311-90020.

\section{References}

Aronowitz A. A. (2009). Human Trafficking, Human Misery: The Global Trade in Human Beings. London, 2009. pp. 12. DOI 10.1080/17440572.2012.754350

Adjusted net national income per capita (current US\$) (2019). Available at: https://data.worldbank.org/indicator/NY.ADJ.NNTY.PC.CD. (accessed 14.09.2019).

Adolescent fertility rate (births per 1,000 women ages 15-19) (2019). Available at: https://data.worldbank.org/indicator/sp.ado.tfrt (accessed 10.10.2019).

Battle-related deaths (number of people) (2019). Available at: https://data.worldbank.org/indicator/ VC.BTL.DETH. (accessed 16.10.2019).

Birth rate, crude (per 1,000 people) (2019). Available at: https://data.worldbank.org/indicator/(accessed 01.11.2019).

Cameron S., Newman E. (2008). Trafficking in humans - Social, political and cultural dimensions. Hong Kong, 2008. pp. 21

Corruption Perceptions Index (2019). Available at: https://www.transparency.org/research/cpi/overview. (accessed 16.10.2019). 
REVISTA DE LA UNIVERSIDAD DEL ZULIA. 3época. Año $12 \mathrm{~N}^{\circ}$ 34, 2021

Yulia A. Siluyanova // Trafficking in persons: cluster analysis of sending and receiving countries, 317-340 DOI: http://dx.doi.org/10.46925//rdluz.34.19

Death rate, crude (per 1,000 people) (2019). Available at: https://data.worldbank.org/indicator/sp.dyn.cdrt.in (accessed 10.10.2019).

Death rate, crude (per 1,000 people) (2019). Available at: https:/data.worldbank.org/indicator/sp.dyn.cdrt.in (accessed 10.10.2019).

Employment to population ratio, ages 15-24, total (\%) (modeled ILO estimate) (2019) Available at: https://data.worldbank.org/indicator/sl.emp.1524.sp.zs. (accessed 14.09.2019).

Fertility rate, total (births per woman) (2019). Available at: https:/data.worldbank.org/ indicator/SP.DYN.TFRT.IN (accessed 10.10.2019).

Gender Inequality Index (2019). Available at: http:/hdr.undp.org/en/composite/GII. (accessed 14.09.2019).

GINI index (World Bank estimate). (2019) Available at: https:/data.worldbank.org/indicator/SI.POV.GINI. (accessed 14.09.2019).

Global Peace Index (2019). Available at: http://visionofhumanity.org/indexes/global-peaceindex/ (accessed 16.10.2019).

Global Slavery Index 2018 (2018). Available at: https://www.globalslaveryindex.org/resources/downloads/ (accessed 10.11.2019).

Government expenditure on education, total (\% of GDP) (2019). Available at: https://ata.worldbank.org/indicator/SE.XPD.TOTL.GD.ZS. (accessed 16.10.2019).

ILO says forced labour generates annual profits of US\$ 150 billion (2014). Available at: https://www.ilo.org/global/about-the-ilo/newsroom/news/WCMS_243201/lang--

en/index.html (accessed 18.04.2021).

Incidence of tuberculosis (per 100,000 people) (2019). Available at: https:/data.worldbank.org/ indicator/sh.tbs.incd. (accessed 16.10.2019).

Inflation, GDP deflator (annual \%) (2019). Available at: https://data.worldbank.org/indicator/NY.GDP.DEFL.KD.ZG. (accessed 14.09.2019).

International migrant stock (\% of population) (2019). Available at: https:/data.worldbank.org/ indicator/SM.POP.TOTL.ZS (accessed 14.09.2019).

International Organization for Migration Available at: https://www.ctdatacollaborative.org/map (accessed 01.11.2019).

Key charts on Education (2019). Available at: https:/www.oecd.org/gender/data/education/. (accessed 16.10.2019).

Lanier M., Henry, S. (2004). Essential Criminology. (2nd ed.)/ USA, 2004. pp. 90]; DOI $10.4324 / 9780429496592$ 
REVISTA DE LA UNIVERSIDAD DEL ZULIA. 3época. Año $12 \mathrm{~N}^{\circ}$ 34, 2021

Yulia A. Siluyanova // Trafficking in persons: cluster analysis of sending and receiving countries, 317-340

DOI: http://dx.doi.org/10.46925//rdluz.34.19

Literacy rate (2019). Available at: http://data.uis.unesco.org/Index.aspx?queryid=166. (accessed 16.10.2019).

Life expectancy at birth, total (years) (2019). Available at: https://data.worldbank.org/indicator/ SP.DYN.LE00.IN (accessed 10.10.2019).

List of countries by forest area (2019). Available at: https://en.wikipedia.org/wiki/List_of_countries_by_forest_area. (accessed 16.10.2019).

Mid-Year Trends 2017 (2017). Available at: https://www.unhcr.org/5aaa4fd27.pdf (accessed 14.09.2019).

Migration and Remittances Data (2019). Available at: https:/www.worldbank.org/en/topic/migrationremittancesdiasporaissues/brief/migrationremittances-data (accessed 14.09.2019).

Mobile cellular subscriptions (per 100 people) (2019). Available at: https://data.worldbank.org/ indicator/IT.CEL.SETS.P2 (accessed 14.09.2019).

Population ages 65 and above, total (2019). Available at: https://data.worldbank.org/indicator/SP.POP.65UP.TO (accessed 10.10.2019).

Population ages 0-14 (\% of total population) (2019). Available at: https://data.worldbank.org/indicator/SP.POP.0014.TO.ZS (accessed 10.10.2019).

Population data (2019). Available at: https://population.un.org/ (accessed 01.11.2019).

Population growth (annual \%) (2019). Available at: https:/data.worldbank.org/indicator/ SP.POP.GROW (accessed 10.10.2019).

Proportion of seats held by women in national parliaments (\%) (2019). Available at: https://data.worldbank.org/indicator/sg.gen.parl.zs. (accessed 14.09.2019).

Prevalence of undernourishment (\% of population) (2019). Available at: https://data.worldbank.org/indicator/sn.itk.defc.zs. (accessed 16.10.2019).

Refugee population by country or territory of asylum (2019). Available at: https://data.worldbank.org/indicator/SM.POP.REFG (accessed 14.09.2019).

Rural population (\% of total population) (2019). Available at: https://data.worldbank.org/indicator/SP.RUR.TOTL.ZS. (accessed 16.10.2019).

Shelley L. (2010). Human Trafficking: A Global Perspective. Cambridge, 2010. pp. 52-53.

Siddharth K. (2009). Sex Trafficking: Inside the Business of Modern Slavery. New York: Chichester, 2009. pp. 31. DOI 10.1007/sl2142-011-0192-0

Siluyanova Yu. A. (2019). Faktory, sposobstvuyushchie razvitiyu industrii torgovli lyud'mi v Rossii i v mire [Factors contributing to the development of the human trafficking industry 
REVISTA DE LA UNIVERSIDAD DEL ZULIA. 3época. Año $12 \mathrm{~N}^{\circ}$ 34, 2021

Yulia A. Siluyanova // Trafficking in persons: cluster analysis of sending and receiving countries, 317-340 DOI: http://dx.doi.org/10.46925//rdluz.34.19

in Russia and in the world]. Public administration, Electronic Bulletin, 2019, no. 77. pp. 84110. DOI 10.24411/2070-1381-2019-10019.

Total natural resources rents (\% of GDP) (2019). Available at: https://data.worldbank.org/indicator/NY.GDP.TOTL.RT.ZS. (accessed 14.09.2019).

Unemployment, total (\% of total labor force) (modeled ILO estimate) (2019). Available at: https://data.worldbank.org/indicator/SL.UEM.TOTL.ZS. (accessed 14.09.2019).

UNESCO World Heritage Centre (2019). Available at: https://whc.unesco.org/en/list/\&order=country. (accessed 16.10.2019).

World Happiness Report 2018 (2018). Available at: https://world happiness.report/ed/2018/(accessed 16.10.2019). 